\title{
THE ROLE OF OUTCASTING IN THE WORLD ORDER
}

Professor dr. juris Geir Ulfstein

Department of Public and International Law, University of Oslo.

\section{Introduction}

The Internationalists is a fascinating book. ${ }^{1}$ The authors present a clear proposition about the significance of the 1928 Pact for the Renunciation of War for a more peaceful world. The volume weaves together the small and big history with its biographies of well-known figures in international law and their significance for the Peace Pact. Well-written and fast-paced, the book keeps a firm grip on the reader throughout.

While the authors place key emphasis on the significance of the 1928 Pact, they recognize that the Pact was not enough: 'If war were truly outlawed, something else had to replace it. Nothing had.' ${ }^{2}$ Consequently, they ask what could replace war in the New World Order.

The authors argue that there were four pillars of this new system - what they call a 'photo negative of the Old World Order': conquest is illegal; aggression is a crime; no coerced agreements are allowed; and sanctions against violators are permitted. ${ }^{3}$ But it is the possibility of outcasting that substituted for war in the New Order. They claim that 'in the New World Order, states have developed a rich set of tools to replace war as a way of enforcing international law - tools we call outcasting. ${ }^{4}$

My focus is on the role of outcasting in the New World Order and the special function of international institutions, including international courts and tribunals. I discuss what outcasting is, and explore its possibilities and limits. Finally, I examine current threats to the present World Order.

\section{What is outcasting?}

The authors define outcasting as 'when a group denies those who break its rules the benefits available to the rest of the group'. ${ }^{5}$ The book recounts outcasting as known in the Norse tradition, including in Iceland. ${ }^{6}$ But, as the authors note, the strategy of outcasting is found in the stories of Adam and Eve, and Cain and Abel. ${ }^{7}$

The authors claim:

'In place of war, international law relies on outcasting. The 1969 Vienna Convention on the Law of Treaties ... states that a breach of an important provision of a treaty

\footnotetext{
${ }^{1}$ O Hathaway and SJ Shapiro, The Internationalists: How a Radical Plan to Outlaw War Remade the World (Simon \& Schuster, New York, 2017).

${ }^{2}$ See (note 1), 273.

${ }^{3}$ See (note 1), 304.

${ }^{4}$ See (note 1), 370. The authors have earlier discussed outcasting in more depth, see O Hathaway and SJ Shapiro, 'Outcasting: Enforcement in Domestic and International Law' (2011) 121 The Yale Law Journal 2, $252-$ 349.

${ }^{5}$ See (note 1), 375 .

${ }^{6}$ See (note 1$), 373$.

${ }^{7}$ See (note 1), 375 .
} 
entitles any affected party to terminate it or suspend its operation in whole or in part. This means that if a state fails to follow a treaty, the states that are affected can refuse to follow it as well. Ironically, international lawyers refer to this peaceful form of retaliation by a military term: "countermeasures.", 8

It is correct that parties violating a treaty may be suspended from the rights of the treaty, or their treaty rights may be terminated. But technically speaking, the Vienna Convention does not regulate countermeasures. As the authors correctly state, countermeasures are regulated in the law on state responsibility - where the International Law Commission's (ILC) Draft Articles on Responsibility of States for Internationally Wrongful Acts of 2001 is of particular importance. ${ }^{9}$ This raises the question of the relationship between countermeasures and outcasting.

\section{Substantive aspects of outcasting}

The use of countermeasures in international law is not new, and long predates the 1928 Pact. In earlier times, countermeasures were known as 'reprisals' or 'self-help'. Hence, countermeasures have hardly replaced war. What is new is that as a result of the Pact and subsequent developments the use of armed force - including war - is prohibited as a countermeasure. Furthermore, the conditions for use of countermeasures and their limits are set out in the ILC Draft. Thus, in stark contrast with the Norse tradition, where an actor subject to outcasting was literally beyond the protection of the law, the New World Order contains complex rules that both authorize and constrain the use of countermeasures.

Despite these rules, however, significant issues remain unresolved. One is the extent to which countermeasures may be taken by non-injured states. ILC Draft article 54 contains a savings clause, whereby the proposed rules do not 'prejudice' the right of non-injured states to take 'lawful measures' against the violating state. This provision was one of the most disputed aspects of the law on countermeasures. ${ }^{10}$ The Commentary to this article points out that '[p]ractice on this subject is limited and rather embryonic'. The lack of guidance in state practice and in the Draft Articles represent an unsatisfactory legal vagueness, and entails risks of misuse.

Perhaps more importantly, under the ILC formulation countermeasures retain their character as private justice. Thus, the decision to apply countermeasures is made by individual states, and does not require institutional authorization. This limits their effectiveness and increases the potential for abuse.

\section{Institutional aspects of outcasting}

The authors emphasize the importance of international institutions in the New World Order. They say that 'the hallmark of the New World Order was the treaty that led President Bush to

\footnotetext{
${ }^{8}$ See (note 1), 375-376.

${ }^{9}$ International Law Commission, Responsibility of States for Internationally Wrongful Acts (Yearbook of the International Law Commission, 2001, vol. II (Part Two), 2001)

${ }^{10}$ EK Proukaki, The Problem of Enforcement in International Law: Countermeasures, the Non-injured State and the Idea of International Community (Routledge, London, 2010), 85.
} 
back down from his campaign promises in 2003, the GATT' ${ }^{11}$ Further: 'The WTO is like a global Thing', ${ }^{12}$ i.e. the traditional decision-making body in the Norse tradition.

This characterization raises the issue of the relationship between the WTO as an international organization and its dispute settlement system - and the difference between countermeasures as private justice and as international measures.

First, is seems clear that the authors refer to the WTO Dispute Settlement System (DSS), not to the WTO as such. The DSS has been characterized as an afterthought - but, still, the 'jewel in the crown' of the WTO. ${ }^{13}$ One particularly notable feature of this system is that the DSS not only has the power to resolve legal disputes, but also the power to control use of retaliatory measures. It seems to me that it is such internationally controlled countermeasures that we should strive for.

\section{International courts and outcasting}

In possessing the power to authorize - and to limit - the use of countermeasures, the WTO Dispute Settlement System is the exception rather than the rule. Other international courts and tribunals (ICs) can adopt remedies in the form of reparations, but they usually do not have the power to authorize enforcement in the form of retaliatory measures.

This means that ICs can impose new obligations in the form of reparations, rather than take away benefits by authorizing outcasting. This is also the case for the European Court of Human Rights (the ECtHR) - which the authors mention. ${ }^{14}$ The ECtHR has no authority of outcasting in the form of expelling member states from the Council of Europe for massive violations of human rights - or Russia for the use of force in Crimea. Such authority is vested in the political organ of the Council, i.e. Committee of Ministers (Statute of the Council of Europe, article 8).

\section{International organizations and outcasting}

However, the threat of expelling states shows the limits of outcasting. As the authors say: 'No method of enforcement is perfect. And outcasting is no exception'. ${ }^{15}$ One difficulty with outcasting is that it is a very strong sanction, and it may be difficult to obtain sufficient political support for such a drastic measure.

Even more importantly, outcasting may mean that the possibilities of influencing the violating state may be lost. For example, if a state is expelled from the Council of Europe, it may drift further away from respect for democracy and human rights. The suspension of the Soviet Union's voting rights in the UN General Assembly in the early 1960s has been characterized

\footnotetext{
${ }^{11}$ See (note 1), 378 .

${ }^{12}$ See (note 1), 379.

${ }^{13}$ See G Shaffer, M Elsig and S Puig, 'The Extensive (But Fragile) Authority of the WTO Appellate Body', (2016) 79 Law and Contemporary Problems 1, 237-275, at 246, with further references.

${ }^{14}$ See (note 1), 382-385.

${ }^{15}$ See (note 1), 381.
} 
as 'a spectacular failure'. ${ }^{16}$ Therefore, even if states violate fundamental rights, the principal rule should be continued inclusion, rather than outcasting.

We have in recent decades experienced extensive international judicialization. Nonetheless, the use of countermeasures are not under sufficient international control. What is more: we lack ICs in important issue areas. And effective remedies and the enforcement of court orders are wanting. Therefore, the problem remains: what can effectively replace the use of force by states? My response is that we need a more varied set of responses against violators - both in the form of withdrawal of benefits and by imposition of sanctions - to be controlled by international institutions, including by ICs.

\section{Threats to the international order}

The authors argue, correctly, that outcasting is not without setbacks ${ }^{17}$ and that the New World Order is at risk. ${ }^{18}$ The threats come, inter alia, from the Islamic State (ISIS) and similar terrorist groups, ${ }^{19}$ expansive use of self-defense ${ }^{20}$ and unilateral humanitarian intervention. ${ }^{21}$

The authors point to the essential role of the United States:

'The success of the system depends on the willingness of the United States to continue to play a central role in maintaining the legal order in the face of these many challenges. Indeed, the greatest threat to the New World Order comes from those who wish to abandon this role and turn inward. ${ }^{22}$

This understanding places much emphasis on the positive role of the USA. But today we can ask not only whether USA is turning inwards, but also whether it is currently an active threat to international law? Does the United State itself choose to be an outcast? Do the US attacks on international institutions signal that we are moving back towards the Old World Order?

Hence, an essential question is whether other states should act - and continue to act - without relying on the United States, e.g. on the UN Law of the Sea Convention, the International Criminal Court, the Paris Agreement on climate change, the Iran deal on nuclear armament, and to save the WTO Dispute Settlement System? One can also ask how states and civil society may continue to develop internationally controlled sanctions against violations of international law - possibly without the USA? How can this be done without preempting the possibilities for later participation by the United States?

\footnotetext{
${ }^{16}$ A Chayes and AH Chayes, The New Sovereignty : Compliance with International Regulatory Agreements (Harvard University Press., Cambridge, Mass. 1995), 78.

${ }^{17}$ See (note 1), 395.

18 See (note 1$), 415$.

${ }^{19}$ See (note 1), 416.

${ }^{20}$ See (note 1$), 416$.

${ }^{21}$ See (note 1$), 417$.

${ }^{22}$ See (note 1), 417.
} 


\section{Acknowledgment}

This contribution was supported by the Research Council of Norway through its Centres of Excellence Funding Scheme, project number 223274 PluriCourts - the Legitimacy of the International Judiciary. 